\title{
Polyostotic fibrous dysplasia: a rare cause of pathological fractures in young patients
}

\author{
Markus Ludwig Sagmeister, ${ }^{1}$ George Miller, ${ }^{2}$ Thomas Lorchan Lewis ${ }^{1}$
}

'St George's Hospital, London, UK

${ }^{2}$ King's College London, London, UK

\section{Correspondence to}

Dr Markus Ludwig Sagmeister, markus.sagmeister@doctors. org.uk

Accepted 15 December 2015
CrossMark

To cite: Sagmeister $M L$, Miller G, Lewis TL. BMJ Case Rep Published online: [please include Day Month Year] doi:10.1136/bcr-2015212992

\section{DESCRIPTION}

Polyostotic fibrous dysplasia (PFD) is a sporadic benign skeletal condition that typically presents with bone pain, deformities and pathological fractures. It preferentially affects long bones. Sarcomatous transformation, most commonly osteosarcoma, occurs in $7 \%$ of patients with PFD. ${ }^{1}$ Diagnostic challenges exist as radiographic appearances range from cystic foci to pagetoid or sclerotic lesions. Differential diagnoses include juvenile bone cysts, aneurysmal bone cysts and giant cell tumours. $^{2}$

We describe a case of a 27-year-old woman who had been diagnosed with PFD at the age of 12 years, and who had an extensive history of pathological fractures. On this admission, she presented with inability to weight-bear and pain in her right thigh following a fall from standing height. Plain radiographs showed advanced disease throughout her skeleton. Figure 1 depicts typical changes including bone expansion, multiple wellcircumscribed cystic lesions and thinning of the cortex without periosteal reaction in the pelvis (figure 1A), and in the left tibia and fibula (figure 1B). Figure 2 shows the same changes along with bowing deformity and a pathological displaced transverse fracture of the distal right femur, worsening the pre-existing deformity, immediately after the initial injury (figure 2A) and 10 weeks later with callus formation (figure 2B).

Surgery in PFD is usually reserved for major deformities or fractures. When making decisions regarding surgical repair, poor remodelling, bone quality and residual angulation in the skeletally immature patient should be considered. Owing to a lack of normal cortical bone, intramedullary internal fixation devices are preferred to plate and screws, as they achieve better fracture stabilisation and may correct existing deformities in this patient group. $^{3}$

Displaced femoral fractures are difficult to reduce non-operatively. Nevertheless, surgical intervention was deemed inappropriate in our patient because of concerns surrounding high risk of complications such as periprosthetic fractures associated with our patient's extensive loss of cortical thickness. She was instead managed conservatively with skin traction for 8 weeks followed by intensive physiotherapy and has recovered well, returning to baseline at 3 months postinjury.
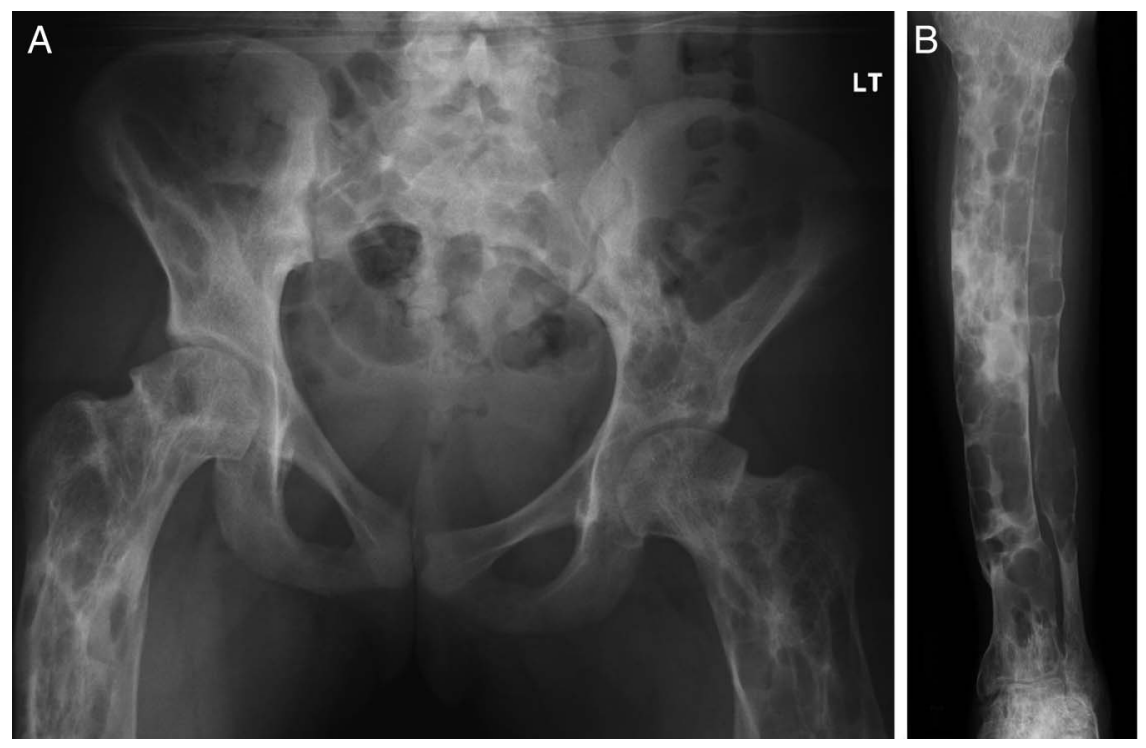

Figure 1 Plain radiographs illustrating extensive bone expansion, cyst formation and cortical loss in (A) the pelvis, (B) the left tibia/fibular. 

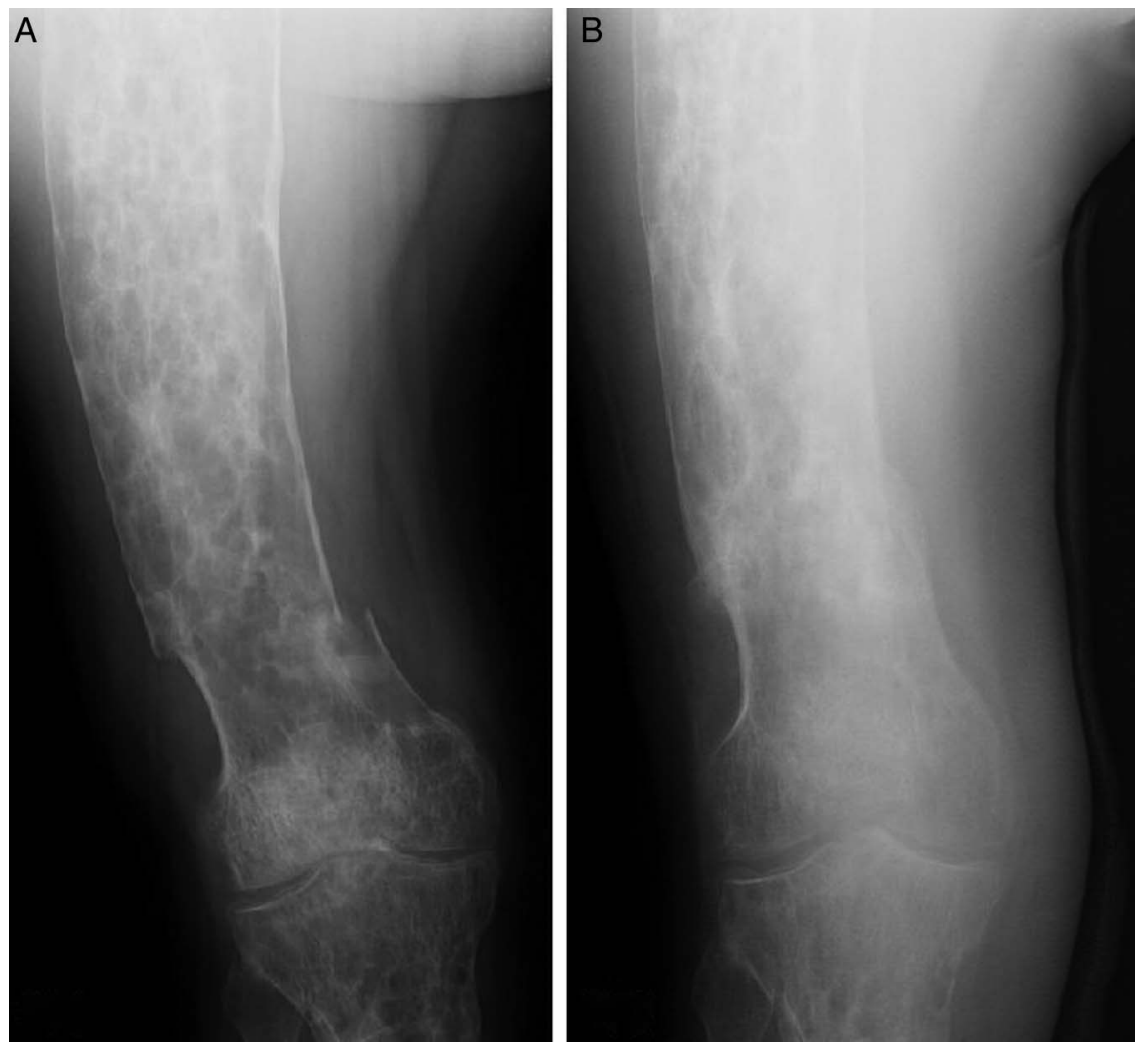

Figure 2 Plain radiographs of the right femur with associated pathological distal transverse fracture (A) immediately after the injury and (B) 10 weeks later with callus formation.

\section{Learning points}

- Polyostotic fibrous dysplasia is a rare complex condition causing bone pain, pathological fractures and progressive deformity in early years.

- Radiological findings vary and include bowing deformity of long bones, bone expansion, cystic or sclerotic foci and thinning of the cortex.

- Primary management for major deformity/fracture is surgical, with preference for intramedullary fixation devices, but conservative management may be appropriate in certain cases.
Contributors MLS prepared the manuscript. GM performed the literature search. TLL consented the patient and revised the manuscript.

Competing interests None declared.

Patient consent Obtained.

Provenance and peer review Not commissioned; externally peer reviewed.

\section{REFERENCES}

1 Ruggieri P, Sim FH, Bond JR, et al. Malignancies in fibrous dysplasia. Cancer 1994;73:1411-24.

2 Endres $S$, Wilke A. Fibrous dysplasia-differential diagnosis of cystic lesions in the proximal femur: a case report. Cases J 2009:2:26.

3 Stanton R, Ippolito E, Springfield D, et al. The surgical management of fibrous dysplasia of bone. Orphanet J Rare Dis 2012;7(Suppl 1):S1.

Copyright 2016 BMJ Publishing Group. All rights reserved. For permission to reuse any of this content visit http://group.bmj.com/group/rights-licensing/permissions.

BMJ Case Report Fellows may re-use this article for personal use and teaching without any further permission.

Become a Fellow of BMJ Case Reports today and you can:

- Submit as many cases as you like

- Enjoy fast sympathetic peer review and rapid publication of accepted articles

- Access all the published articles

- Re-use any of the published material for personal use and teaching without further permission

For information on Institutional Fellowships contact consortiasales@bmjgroup.com

Visit casereports.bmj.com for more articles like this and to become a Fellow 